\title{
Globular Flower-Like Reduced Graphene Oxide Design for Enhancing Thermally Conductive Properties of Silicone-Based Spherical Alumina Composites
}

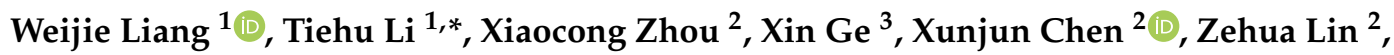 \\ Xiaoyan Pang ${ }^{2}$ and Jianfang Ge ${ }^{2, *(D)}$ \\ 1 Shaanxi Engineering Laboratory for Graphene New Carbon Materials and Applications, School of Materials \\ Science and Engineering, Northwestern Polytechnical University, Xi'an 710072, China; \\ leungvijer@mail.nwpu.edu.cn \\ 2 Guangdong Engineering Research Center of Silicone Electronic Fine Chemicals, College of Chemistry and \\ Chemical Engineering, Zhongkai University of Agriculture and Engineering, Guangzhou 510225, China; \\ zhouxiaocong@zhku.edu.cn (X.Z.); chenxj@zhku.edu.cn (X.C.); linzehua@zhku.edu.cn (Z.L.); \\ shellypxy@zhku.edu.cn (X.P.) \\ 3 School of Materials and Energy, Guangdong University of Technology, Guangzhou 510006, China; \\ 1111902004@gdut.edu.cn \\ * Correspondence: litiehu@nwpu.edu.cn (T.L.); gejianfang@zhku.edu.cn (J.G.); \\ Tel.: +86-029-88460337 (T.L.); +86-020-34172972 (J.G.)
}

Received: 16 February 2020; Accepted: 12 March 2020; Published: 18 March 2020

\begin{abstract}
The enhancement of thermally conductive performances for lightweight thermal interface materials is a long-term effort. The superb micro-structures of the thermal conductivity enhancer have an important impact on increasing thermal conductivity and decreasing thermal resistance. Here, globular flower-like reduced graphene oxide (GFRGO) is designed by the self-assembly of reduced graphene oxide (RGO) sheets, under the assistance of a binder via the spray-assisted method for silicone-based spherical alumina $\left(\mathrm{S}-\mathrm{Al}_{2} \mathrm{O}_{3}\right)$ composites. When the total filler content is fixed at $84 \mathrm{wt} \%$, silicone-based $\mathrm{S}-\mathrm{Al}_{2} \mathrm{O}_{3}$ composites with $1 \mathrm{wt} \%$ of GFRGO exhibit a much more significant increase in thermal conductivity, reduction in thermal resistance and reinforcement in thermal management capability than that of without graphene. Meanwhile, GFRGO is obviously superior to that of their RGO counterparts. Compared with RGO sheets, GFRGO spheres which are well-distributed between the $\mathrm{S}-\mathrm{Al}_{2} \mathrm{O}_{3}$ fillers and well-dispersed in the matrix can build three-dimensional and isotropic thermally conductive networks more effectively with $\mathrm{S}-\mathrm{Al}_{2} \mathrm{O}_{3}$ in the matrix, and this minimizes the thermal boundary resistance among components, owning to its structural characteristics. As with $\mathrm{RGO}$, the introduction of GFRGO is helpful when decreasing the density of silicone-based $\mathrm{S}-\mathrm{Al}_{2} \mathrm{O}_{3}$ composites. These attractive results suggest that the strategy opens new opportunities for fabricating practical, high-performance and light-weight filler-type thermal interface materials.
\end{abstract}

Keywords: reduced graphene oxide; spherical alumina; density; thermally conductive properties

\section{Introduction}

With the development of microelectronics, there is a tide towards miniaturization and multifunctionalization in the area of modern electric devices. It means that more heat is generated by electronic components in the devices. In order to ensure reliable operation, efficient heat removal from devices is being taken increasingly seriously. Thermal interface materials, which serve as heat transfer bridges, have played a part in the thermal management of packaging and heat-generating electronic 
devices [1-3]. According to different applications, thermal interface materials can be divided into several groups. Thereinto, filler-type thermal interface materials have been drawing much attention because of their reasonable performance, ease of application and inexpensive price [4-6]. As a response to the new challenge of heat dissipation, many researchers have focused on their thermally conductive properties. The significant enhancement of thermally conductive properties is directly relevant to the addition of fillers, such as ceramic filler [7], metallic stuffing [8], carbonic materials [9] and hybrid particles [10].

As one of many ceramic fillers, alumina $\left(\mathrm{Al}_{2} \mathrm{O}_{3}\right)$ displays some benefits, and has been commonly used in thermal interface materials in terms of high electrical resistivity, chemical inertness and low cost, although its thermal conductivity is not exceptionally high [11-13]. $\mathrm{Al}_{2} \mathrm{O}_{3}$ with different morphologies, such as spherical [14], branched [15], fibrous [16] and irregular [17] were demonstrated to be thermal conductors in the polymeric composites. In view of the viscosity of polymer composites during processing, spherical $\mathrm{Al}_{2} \mathrm{O}_{3}\left(\mathrm{~S}-\mathrm{Al}_{2} \mathrm{O}_{3}\right)$ has been widely applied in virtue of its characteristic of high packing density. Naturally, the reported polymer-based $\mathrm{S}-\mathrm{Al}_{2} \mathrm{O}_{3}$ composites can achieve a relative high value of thermal conductivity under a high loading of $\mathrm{S}^{-} \mathrm{Al}_{2} \mathrm{O}_{3}$ [18-20]. However, the loading of very large $\mathrm{S}-\mathrm{Al}_{2} \mathrm{O}_{3}$ leads to an inevitable increase in density of the polymer composites only filled with $\mathrm{S}-\mathrm{Al}_{2} \mathrm{O}_{3}$. Ideal thermal interface materials with low density and excellent thermally conductive properties are required for commercial and practical application. With the help of other fillers with lightweight and extraordinarily high thermal conductivity, the partial replacement method is a simple and effective method to decrease density and enhance the thermally conductive properties of polymer-based $\mathrm{S}-\mathrm{Al}_{2} \mathrm{O}_{3}$ composites. For example, the alliance of $\mathrm{S}-\mathrm{Al}_{2} \mathrm{O}_{3}$ with graphene nanoplatelets resulted in a $6 \%$ reduction in density and $47.1 \%$ increase in thermal conductivity, compared to neat $\mathrm{S}-\mathrm{Al}_{2} \mathrm{O}_{3}$-filled silicone rubber composites [21]. It is feasible to replace partial S- $\mathrm{Al}_{2} \mathrm{O}_{3}$ with graphene in the filler system for composites.

Graphene, a two-dimensional (2D) carbonic materials with a one-atom-thick single layer comprised of $\mathrm{sp}^{2}$-bonded carbon, has been discovered to have good application prospects for the thermal management of electronics, due to its chemical and physical characteristics, such as ultrahigh thermal conductivity, excellent electrical conductivity, and lightweight as well as good chemical stability [22-24]. A rational micro-structure design of individual graphene has become attractive. Wu et al. [25] successfully constructed three-dimensional (3D) graphene flower cluster patterns, which presented outstanding sensor responses of $\mathrm{NO}_{2}$ for reversible gas sensing. Chen et al. [26] synthesized high-quality graphene microflower and gave evidence of its unique merits for the improvement of the electrochemical performances of Li-S \& Al-ion batteries. Also, the graphene microflowers by Chen et al. [27] can also be used for high-performance microwave absorption. However, there are scarce researches about graphene with above peculiar morphology used as thermal conductivity additives. Moreover, it is evidenced that the shape of filler from platelet-like to stable spherical is a viable option for improving the performance of filler-type thermal interface materials [28]. This inspired us to design globular flower-like reduced graphene oxide (GFRGO) for high-performance and lightweight polymer-based S- $\mathrm{Al}_{2} \mathrm{O}_{3}$ composites.

In this paper, GFRGO was prepared by the self-assembly of reduced graphene oxide (RGO) sheets with the assistance of binder via the spray-assisted method and following chemical pre-reduction and a thermal annealing procedure. The obtained GFRGO had a globular flower-like shape. As a thermal conductivity enhancer, GFRGO with good shape stability is an appealing and promising substitution for a fraction of $\mathrm{S}-\mathrm{Al}_{2} \mathrm{O}_{3}$. A small amount of GFRGO was introduced into Polydimethylsiloxane (PDMS) with a large amount of S- $\mathrm{Al}_{2} \mathrm{O}_{3}$ to form GFRGO/S- $\mathrm{Al}_{2} \mathrm{O}_{3} / \mathrm{PDMS}$ composites, employing an in situ blending method. The density and thermally conductive properties of GFRGO/S- $\mathrm{Al}_{2} \mathrm{O}_{3} / \mathrm{PDMS}$ composites were investigated. 


\section{Materials and Methods}

\subsection{Materials}

The graphene oxide (GO) was synthesized according to our previous work [29]. The binder polyvinyl alcohol (PVA, BP-17) was produced by Chang Chun Chemical (Jiangsu) Co., Ltd. (Changshu, China). L-ascorbic acid (L-AA) was supplied by Sanpu Fine Chemical Factory (Xi'an, China). Polydimethylsiloxane (PDMS, $500 \mathrm{mPa} \cdot \mathrm{s}$ ) was by Shenzhen Xinya New Materials Co., Ltd. (Shenzhen, China). Spherical alumina powder $\left(\mathrm{S}-\mathrm{Al}_{2} \mathrm{O}_{3}, 10 \mu \mathrm{m}\right)$ was made in AnHui Estone Materials Technology Co., Ltd. (Bengbu, China). DOWSIL 11-100 additive was purchased from the Dow Chemical Company (Midland, MI, USA).

\subsection{Preparation of $G F R G O$}

The GFRGO was obtained by the spray-drying granulation technique, chemical pre-reduction and thermal annealing procedure. Firstly, 2 g GO were added into $1000 \mathrm{~mL}$ deionized water by ultrasonication for $180 \mathrm{~min}$. Secondly, $0.4 \mathrm{~g} 5 \mathrm{wt} \%$ PVA aqueous solution was added drop wise into the dispersion, with magnetic stirring for $40 \mathrm{~min}$ at $65^{\circ} \mathrm{C}$. After that, the mixture was nebulized into small droplets under $150{ }^{\circ} \mathrm{C}$ by the spray dryer. The atomized droplets evaporated in a few seconds and converted into dried globular flower-like GO (GFGO) granules, with the help of the binder PVA. The dried GFGO powders were gathered in the collector. The sample was treated with $0.1 \mathrm{~g} / \mathrm{L} \mathrm{L}-\mathrm{AA}$ solution at room temperature until its surface turned brownish black. Next, they were transferred into a tube furnace in argon at $1400{ }^{\circ} \mathrm{C}$ to remove organic additives and obtain sintered globular flower-like GFRGO. Finally, the GFRGO was collected for further application. For comparison, RGO was prepared via the same chemical treatment and thermal annealing procedure by using GO as a raw material.

\subsection{Preparation of GFRGO/S- $\mathrm{Al}_{2} \mathrm{O}_{3} / P D M S$ Composites}

The GFRGO/S- $\mathrm{Al}_{2} \mathrm{O}_{3} / \mathrm{PDMS}$ composites were prepared by an in situ blending method. Firstly, PDMS mixed with a small amount of DOWSIL 11-100 additive was stirred at $30{ }^{\circ} \mathrm{C}$ for $10 \mathrm{~min}$. The dosage of DOWSIL 11-100 additive was $0.9 \%$, based on the weight of GFRGO and $\mathrm{S}-\mathrm{Al}_{2} \mathrm{O}_{3}$. Secondly, GFRGO and $\mathrm{S}-\mathrm{Al}_{2} \mathrm{O}_{3}$, with different weight ratios, were compounded with the above mixture for $4 \mathrm{~min}$ at the speed of $2200 \mathrm{rpm}$, in the automatic rev-rot gravity mixer (VM300SA20, SINOMIX, Mianyang, China). The mixing process was repeated 3-6 times to get a well-dispersed slurry. Subsequently, the as-received slurry was milled at $80^{\circ} \mathrm{C}$ using a three-roller machine. In order to obtain a homogeneous compound, the as-prepared GFRGO/S- $\mathrm{Al}_{2} \mathrm{O}_{3} / \mathrm{PDMS}$ composites was milled 3-6 times. The overall preparation process for GFRGO/S- $\mathrm{Al}_{2} \mathrm{O}_{3} / \mathrm{PDMS}$ composites is provided in Figure 1. For comparison, $\mathrm{S}-\mathrm{Al}_{2} \mathrm{O}_{3} / \mathrm{PDMS}$ and $\mathrm{RGO} / \mathrm{S}-\mathrm{Al}_{2} \mathrm{O}_{3} / \mathrm{PDMS}$ composites were prepared using the same method.

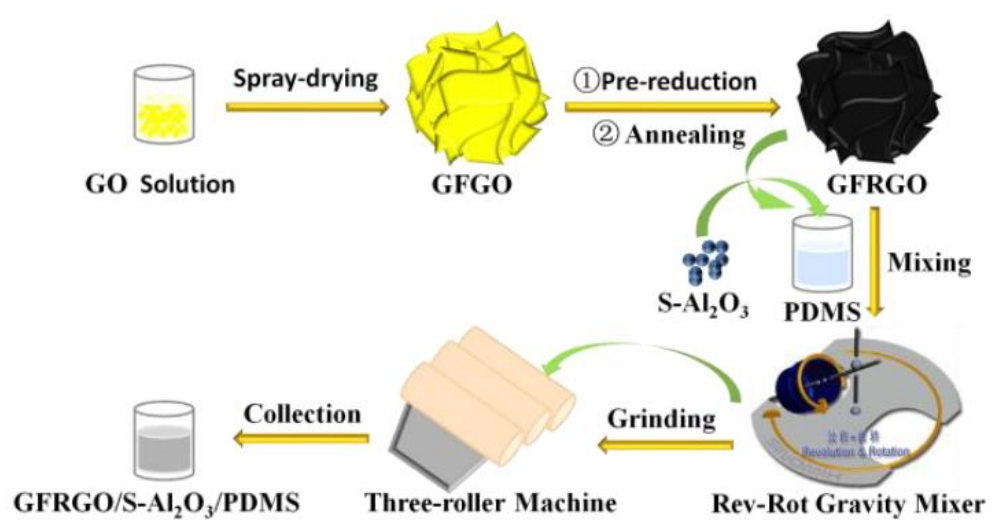

Figure 1. Scheme for the preparation of GFRGO/S- $\mathrm{Al}_{2} \mathrm{O}_{3} / \mathrm{PDMS}$ composites. 


\subsection{Characterization}

Scanning electron microscopy (EVO18, Carl Zeiss, Jena, Germany), X-ray diffraction patterns (XRD, D8 ADVANCE, Bruker AXS, Karlsruhe, Germany) and the Raman scattering spectrum (LabRAM HR800, HORIBA Scientific, Lat Krabang, Thailand) were employed to analyze the surface morphology, structural characteristics and components composition of $\mathrm{S}-\mathrm{Al}_{2} \mathrm{O}_{3}, \mathrm{RGO}$ and GFRGO. The density of $\mathrm{S}-\mathrm{Al}_{2} \mathrm{O}_{3} / \mathrm{PDMS}$, RGO/S- $\mathrm{Al}_{2} \mathrm{O}_{3} / \mathrm{PDMS}$ and GFRGO/S- $\mathrm{Al}_{2} \mathrm{O}_{3} / \mathrm{PDMS}$ composites were measured by a density cup (QBB-37, Modern Instruments, Shanghai, China). The thermal conductivity of S- $\mathrm{Al}_{2} \mathrm{O}_{3} / \mathrm{PDMS}$, RGO/S- $\mathrm{Al}_{2} \mathrm{O}_{3} / \mathrm{PDMS}$ and GFRGO/S- $\mathrm{Al}_{2} \mathrm{O}_{3} / \mathrm{PDMS}$ composites was examined by a thermal conductivity meter (DRL-III, Xiangyi, Xiangtan, China), using the heat flow method. The thermal resistance of $\mathrm{S}-\mathrm{Al}_{2} \mathrm{O}_{3} / \mathrm{PDMS}, \mathrm{RGO} / \mathrm{S}-\mathrm{Al}_{2} \mathrm{O}_{3} / \mathrm{PDMS}$ and GFRGO/S- $\mathrm{Al}_{2} \mathrm{O}_{3} / \mathrm{PDMS}$ composites was tested by a thermal resistance and conductivity measurement apparatus (LW-9389, Longwin, Taoyuan, Taiwan) based on ASTM D 5470-06 Standard. The thermal management capability of S- $\mathrm{Al}_{2} \mathrm{O}_{3} / \mathrm{PDMS}$, RGO/S- $\mathrm{Al}_{2} \mathrm{O}_{3} / \mathrm{PDMS}$ and GFRGO/S- $\mathrm{Al}_{2} \mathrm{O}_{3} / \mathrm{PDMS}$ composites was performed by a thermal infrared camera (TiS10, Fluke, MA, USA).

\section{Results and Discussion}

\subsection{Morphology and Structure of $\mathrm{S}-\mathrm{Al}_{2} \mathrm{O}_{3}$ and GFRGO}

The morphologies of $\mathrm{S}-\mathrm{Al}_{2} \mathrm{O}_{3}, \mathrm{RGO}$ and GFRGO at different magnifications are displayed in Figure 2. It is obvious that the particles of pristine $\mathrm{S}-\mathrm{Al}_{2} \mathrm{O}_{3}$ possess an ultra-high spherical rate in Figure $2 \mathrm{a}$. The diameter of most of the spheres is about $10 \mu \mathrm{m}$. The size $\mathrm{S}-\mathrm{Al}_{2} \mathrm{O}_{3}$ can contribute to the major thermally conductive pathways in PDMS matrix. There are a tiny proportion of the smaller size $\mathrm{S}-\mathrm{Al}_{2} \mathrm{O}_{3}$. It can be served as the point of junction between large sizes of $\mathrm{S}-\mathrm{Al}_{2} \mathrm{O}_{3}$ to create more contact. Figure $2 \mathrm{~b}$ is a picture of the selected blue and rectangular region of $\mathrm{S}-\mathrm{Al}_{2} \mathrm{O}_{3}$ under high magnification. The surface of $\mathrm{S}-\mathrm{Al}_{2} \mathrm{O}_{3}$ is a bit rough. A few nanoparticles adhere to it. The surface of $\mathrm{S}-\mathrm{Al}_{2} \mathrm{O}_{3}$ makes it possible for conjunctions between $\mathrm{S}-\mathrm{Al}_{2} \mathrm{O}_{3}$ and other fillers to occur, which facilitate heat transportation. The SEM image of as-synthesized RGO after ultrasonic treatment is shown in Figure 2c. Some RGO sheets with a few layers are randomly scattered on the conductive film. Figure $2 \mathrm{~d}$ is an enlarged image of the green and rectangular zone in Figure 2c. The edges of the bare RGO partially curl and the RGO exhibits some folds on its surface in Figure $2 d$. The graphene structure is favorable for assembling into a special structural filler. Figure $2 \mathrm{e}$ shows the picture of the sintered GFRGO. The as-prepared GFRGO has a globular flower-like shape, with the size of about $14 \mu \mathrm{m}$. The shape and size of GFRGO are good for improving the thermally conductive properties of silicone-based $\mathrm{S}-\mathrm{Al}_{2} \mathrm{O}_{3}$ composites. The high magnified image in Figure $2 \mathrm{f}$ reveals that GFRGO consists of the highly folded RGO, which interlock with each other. The wrinkled RGO bonds together to form a three-dimensional and crumpled cluster configuration, with ridges and vertices aided by PVA, as a binder via a spray-drying procedure. The spheroidal flower-shaped GFRGO is strong enough to limit disintegration from the mechanical blending during the mixing with polymer matrix. This structure is beneficial for forming an efficient heat conduction channel with $\mathrm{S}-\mathrm{Al}_{2} \mathrm{O}_{3}$ in PDMS.

The structure of $\mathrm{S}-\mathrm{Al}_{2} \mathrm{O}_{3}, \mathrm{RGO}$ and GFRGO were probed by the XRD patterns and Raman spectra (Figure 3). The intense peaks in Figure 3a conform to that of $\alpha$-alumina, indicating the as-used S- $\mathrm{Al}_{2} \mathrm{O}_{3}$ with well-crystallized structure is $\alpha$-alumina [30-32]. The high crystalline quality of $\mathrm{S}-\mathrm{Al}_{2} \mathrm{O}_{3}$ fillers is crucial for the thermal conductive properties of silicone-based $\mathrm{S}-\mathrm{Al}_{2} \mathrm{O}_{3}$ composites. Figure $3 \mathrm{~b}$ shows the XRD spectrums of RGO and GFRGO. The RGO spectrum has a broad peak at $25.9^{\circ}$, signifying the typical multilayered graphene after chemical and thermal reduction. Compared to the RGO, the GFRGO curve shows a moderate sharp peak at $25.9^{\circ}$, a small peak at $43.6^{\circ}$ and a weak at $53.9^{\circ}$, corresponding to (002), (100) and (004), and proving only the loose and disordered stacking of self-folded graphene [26]. The significant change of the spectrums means that RGO spliced into GFRGO. The Raman spectra analysis also give information about the structure of GFRGO (Figure 3c). It can be observed that RGO and GFRGO mainly have three characteristic peaks, D peak $\left(1352 \mathrm{~cm}^{-1}\right)$, 
G peak $\left(1595 \mathrm{~cm}^{-1}\right)$ and $2 \mathrm{D}$ peak $\left(2706 \mathrm{~cm}^{-1}\right)$ [27]. The $\mathrm{I}_{2 \mathrm{D}} / \mathrm{I}_{\mathrm{G}}$ ratio of $\mathrm{GFRGO}$ has a significant decrease compared with RGO, which indicates that RGO sheets build the globular flower-like microstructure of GFRGO. The Raman results confirmed that the GFRGO has been successfully synthesized through adhesive effect by PVA. The architecture of the GFRGO provides the prior condition for the preparation of isotropic silicone-based composites with $\mathrm{S}-\mathrm{Al}_{2} \mathrm{O}_{3}$.

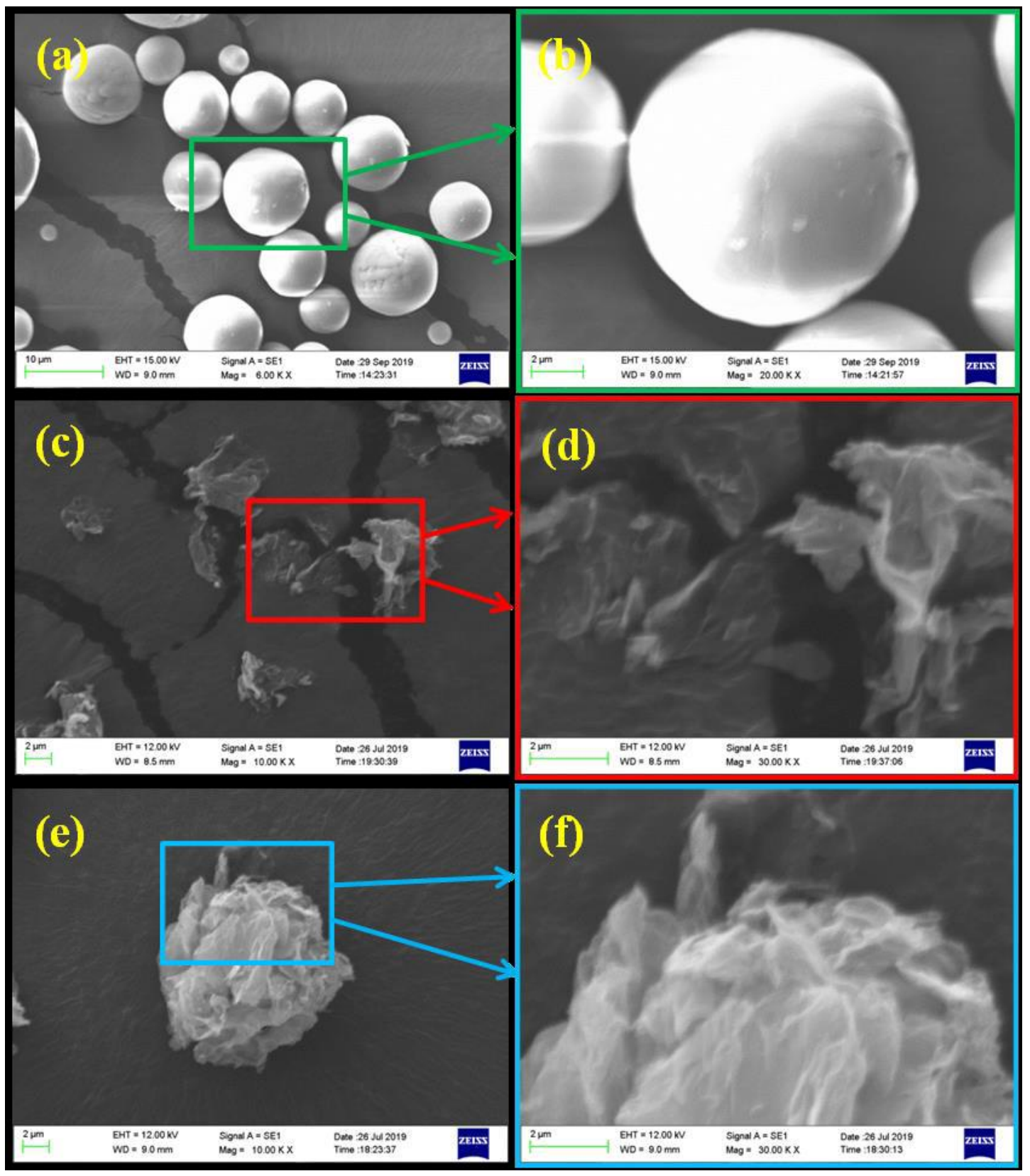

Figure 2. SEM images of $(\mathbf{a}, \mathbf{b}) \mathrm{S}-\mathrm{Al}_{2} \mathrm{O}_{3},(\mathbf{c}, \mathbf{d}) \mathrm{RGO}$ and $(\mathbf{e}, \mathbf{f})$ GFRGO. 

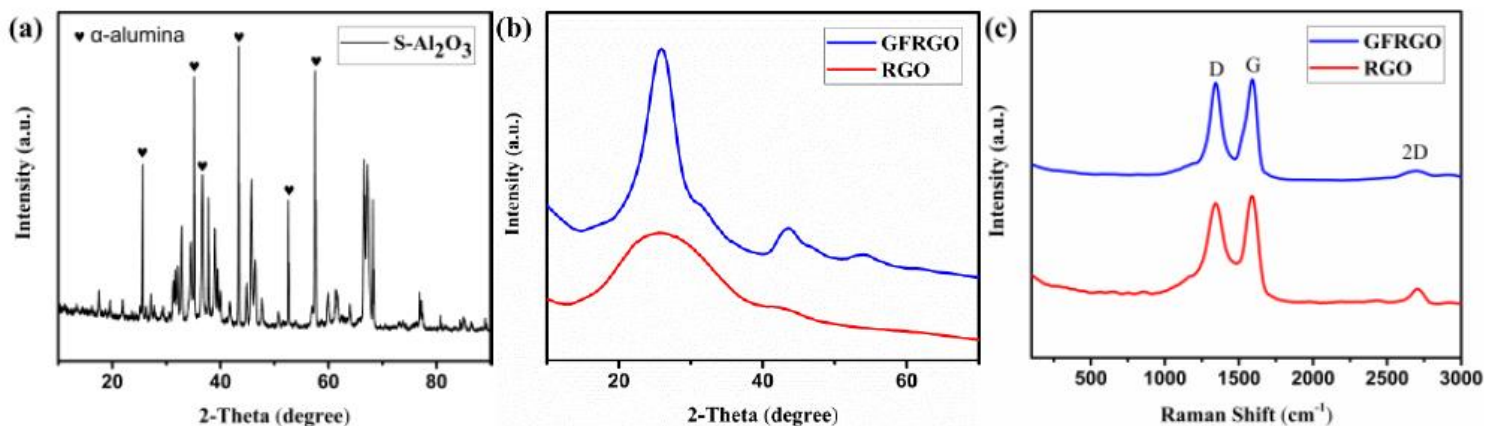

Figure 3. XRD patterns of (a) $\mathrm{S}-\mathrm{Al}_{2} \mathrm{O}_{3},(\mathbf{b}) \mathrm{RGO}$ and GFGRO; (c) Raman spectra of RGO and GFGRO.

\subsection{Density of GFRGO/S- $\mathrm{Al}_{2} \mathrm{O}_{3} / P D M S$ Composites}

Density is a consideration for the silicone-based $\mathrm{S}-\mathrm{Al}_{2} \mathrm{O}_{3}$ composites in the practical application for thermal management. Low density suggests the lightweight feasibility of the product [33]. Figure $4 \mathrm{a}, \mathrm{b}$ show the variation of the density with weight contents of $\mathrm{S}-\mathrm{Al}_{2} \mathrm{O}_{3}, \mathrm{GFRGO} / \mathrm{S}-\mathrm{Al}_{2} \mathrm{O}_{3}$ and $\mathrm{RGO} / \mathrm{S}-\mathrm{Al}_{2} \mathrm{O}_{3}$. For the S- $\mathrm{Al}_{2} \mathrm{O}_{3} / \mathrm{PDMS}$ composites in Figure $4 \mathrm{a}$, the density increases linearly with increasing $\mathrm{S}-\mathrm{Al}_{2} \mathrm{O}_{3}$ content at the $\mathrm{S}-\mathrm{Al}_{2} \mathrm{O}_{3}$ mass fraction below $84 \mathrm{wt} \%$, and afterwards increases significantly, which is due to the fact that the density of $\mathrm{S}-\mathrm{Al}_{2} \mathrm{O}_{3}$ is higher than that of PDMS. When the $\mathrm{S}-\mathrm{Al}_{2} \mathrm{O}_{3}$ content was beyond $88 \mathrm{wt} \%$, the viscosity of $\mathrm{S}-\mathrm{Al}_{2} \mathrm{O}_{3} / \mathrm{PDMS}$ composites became very large, so that the $\mathrm{S}-\mathrm{Al}_{2} \mathrm{O}_{3} / \mathrm{PDMS}$ composites lost their mobility at ambient temperature. In comparison to $\mathrm{S}-\mathrm{Al}_{2} \mathrm{O}_{3}$, graphene can be used to prepare the goal-oriented composites with low density and good heat conduction performances, due to its merits of lightweight and high thermal conductivity. Figure $4 \mathrm{~b}$ shows the density of GFRGO/S- $\mathrm{Al}_{2} \mathrm{O}_{3} / \mathrm{PDMS}$ and $\mathrm{RGO} / \mathrm{S}-\mathrm{Al}_{2} \mathrm{O}_{3} / \mathrm{PDMS}$ composites with graphene, of which the total filler content is fixed at $84 \mathrm{wt} \%$. It is seen that the density of the two kinds of silicone-based S- $\mathrm{Al}_{2} \mathrm{O}_{3}$ composites decreases slightly with the increment of graphene compared to $\mathrm{S}-\mathrm{Al}_{2} \mathrm{O}_{3} / \mathrm{PDMS}$ composites. There is no palpable difference in density between the $\mathrm{S}-\mathrm{Al}_{2} \mathrm{O}_{3} / \mathrm{PDMS}$ composites filled with GFRGO and RGO. The density of S- $\mathrm{Al}_{2} \mathrm{O}_{3} / \mathrm{PDMS}$ composites is $2.55 \mathrm{~g} / \mathrm{cm}^{3}$ at the $\mathrm{S}-\mathrm{Al}_{2} \mathrm{O}_{3}$ content $84 \mathrm{wt} \%$. With $1.0 \%$ graphene, the density of GFRGO/S- $\mathrm{Al}_{2} \mathrm{O}_{3} / \mathrm{PDMS}$ composites is about $2.49 \mathrm{~g} / \mathrm{cm}^{3}$, reduced by about $2.3 \%$. These results indicate that GFRGO can be used as a thermal conductivity enhancer, which has an advantage in the density for silicone-based $\mathrm{S}-\mathrm{Al}_{2} \mathrm{O}_{3}$ composites.

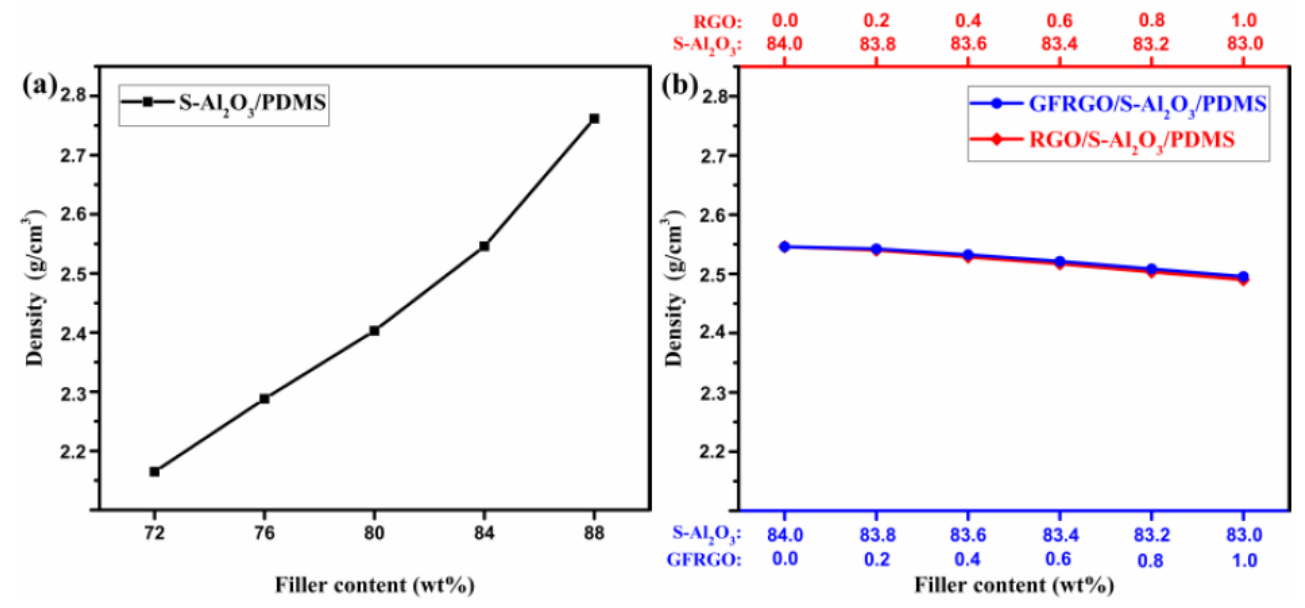

Figure 4. Density of (a) $\mathrm{S}-\mathrm{Al}_{2} \mathrm{O}_{3} / \mathrm{PDMS}$ composites and (b) GFRGO/S- $\mathrm{Al}_{2} \mathrm{O}_{3} / \mathrm{PDMS}$ and $\mathrm{RGO} / \mathrm{S}-\mathrm{Al}_{2} \mathrm{O}_{3} / \mathrm{PDMS}$ composites with different filler contents.

\subsection{Thermally Conductive Properties of GFRGO/S- $\mathrm{Al}_{2} \mathrm{O}_{3} / \mathrm{PDMS}$ Composites}

The thermal conductivity of silicone-based $\mathrm{S}-\mathrm{Al}_{2} \mathrm{O}_{3}$ composites is one of important thermally conductive performances. The thermal conductivity of $\mathrm{S}-\mathrm{Al}_{2} \mathrm{O}_{3}, \mathrm{GFRGO} / \mathrm{S}-\mathrm{Al}_{2} \mathrm{O}_{3}$ and RGO/S- $\mathrm{Al}_{2} \mathrm{O}_{3}$ 
filled PDMS composites are shown in Figure 5a,b. A continuous increase in thermal conductivity of silicone-based $\mathrm{S}-\mathrm{Al}_{2} \mathrm{O}_{3}$ composites is observed, with increasing $\mathrm{S}-\mathrm{Al}_{2} \mathrm{O}_{3}$ loading in Figure 5 a. At the $\mathrm{S}-\mathrm{Al}_{2} \mathrm{O}_{3}$ content of $84 \mathrm{wt} \%$, its thermal conductivity is $1.39 \mathrm{~W} \cdot \mathrm{m}^{-1} \cdot \mathrm{K}^{-1}$ and the workability of $\mathrm{S}-\mathrm{Al}_{2} \mathrm{O}_{3} / \mathrm{PDMS}$ composites is strong. When the $\mathrm{S}-\mathrm{Al}_{2} \mathrm{O}_{3}$ content has been further increased to $88 \%$, its thermal conductivity is $1.68 \mathrm{~W} \cdot \mathrm{m}^{-1} \cdot \mathrm{K}^{-1}$, increased by $21 \%$. At the higher $\mathrm{S}-\mathrm{Al}_{2} \mathrm{O}_{3}$ loading, the thermal conductivity of the silicone-based $\mathrm{S}-\mathrm{Al}_{2} \mathrm{O}_{3}$ composites indeed increases, while its workability become weaker because of the increasing viscosity. An ideal silicone-based $\mathrm{S}-\mathrm{Al}_{2} \mathrm{O}_{3}$ composites possesses strong workability and high thermal conductivity. Combination of two kinds of fillers in composites has been demonstrated to be an effective method to enhance thermal conductivity. In order to maintain strong workability, graphene with higher thermal conductivity was introduced to elevate the thermal conductivity of silicone-based $\mathrm{S}-\mathrm{Al}_{2} \mathrm{O}_{3}$ composites. The values of thermal conductivity of GFRGO/S- $\mathrm{Al}_{2} \mathrm{O}_{3} / \mathrm{PDMS}$ composites are greater than that of $\mathrm{RGO} / \mathrm{S}-\mathrm{Al}_{2} \mathrm{O}_{3} / \mathrm{PDMS}$ composites in Figure 5b. For GFRGO/S- $\mathrm{Al}_{2} \mathrm{O}_{3} / \mathrm{PDMS}$ composites, the contact between globular flower-like GFRGO and spherical S- $\mathrm{Al}_{2} \mathrm{O}_{3}$ is stronger than that between platelet-like $\mathrm{RGO}$ and $\mathrm{S}-\mathrm{Al}_{2} \mathrm{O}_{3}$ in the $\mathrm{RGO} / \mathrm{S}-\mathrm{Al}_{2} \mathrm{O}_{3} / \mathrm{PDMS}$ composites, which reduce the phonon scattering at the interface [28]. For both the GFRGO/S- $\mathrm{Al}_{2} \mathrm{O}_{3} / \mathrm{PDMS}$ and $\mathrm{RGO} / \mathrm{S}-\mathrm{Al}_{2} \mathrm{O}_{3} / \mathrm{PDMS}$ composites, at the graphene content from $0.2 \%$ to $0.6 \%$, the proportion of graphene is too low, so that the thermal conductivity of them increases slowly. However, the thermal conductivity of GFRGO/S- $\mathrm{Al}_{2} \mathrm{O}_{3} / \mathrm{PDMS}$ composites increases faster than that of $\mathrm{RGO} / \mathrm{S}-\mathrm{Al}_{2} \mathrm{O}_{3} / \mathrm{PDMS}$ composites and the gap of enhancement between $\mathrm{GFRGO} / \mathrm{S}-\mathrm{Al}_{2} \mathrm{O}_{3} / \mathrm{PDMS}$ and $\mathrm{RGO} / \mathrm{S}-\mathrm{Al}_{2} \mathrm{O}_{3} / \mathrm{PDMS}$ composites in the thermal conductivity have widened at the graphene content from $0.8 \%$ to $1.0 \%$. Table 1 displays the some polymer-based $\mathrm{S}-\mathrm{Al}_{2} \mathrm{O}_{3}$ composites and their thermal conductivity enhancement. By adding a small portion of other fillers with higher thermal conductivity into polymer-based $\mathrm{S}-\mathrm{Al}_{2} \mathrm{O}_{3}$ composites for replacing the same content of $\mathrm{S}-\mathrm{Al}_{2} \mathrm{O}_{3}$, the thermal conductivity of them is increased compared with that of the corresponding polymer-based $\mathrm{S}-\mathrm{Al}_{2} \mathrm{O}_{3}$ composites, due to the synergistic effect. In our work, the enhanced ability of GFRGO reached $48 \%$, about 2.1 times that of the RGO in filled $\mathrm{S}-\mathrm{Al}_{2} \mathrm{O}_{3} / \mathrm{PDMS}$ composites (23\%), at the filling ratio $1.0 \%$. The GFRGO is a more effective enhancer than RGO for enhancement in the thermal conductivity of silicone-based $\mathrm{S}-\mathrm{Al}_{2} \mathrm{O}_{3}$ composites, which is attributed to the formation of the isotropic, continuous and stable heat-conductive pathways by the 3D near-spherical GFRGO and the spherical S- $\mathrm{Al}_{2} \mathrm{O}_{3}$, as well as the synergistic effect of the binary-filler hybrid [2,34,35]. Thus, the structure and dimensions of GFRGO are in favor of the improvement in the thermal conductivity of silicone-based $\mathrm{S}-\mathrm{Al}_{2} \mathrm{O}_{3}$ composites. Compared with this work, several studies reported higher values of composites with graphene or graphene and boron nitride was achieved in the heat conduction properties at the high filler loading [36-38]. These results were quite enlightening for developing silicone-based $\mathrm{S}-\mathrm{Al}_{2} \mathrm{O}_{3}$ composites, with better heat conduction properties in the later studies.
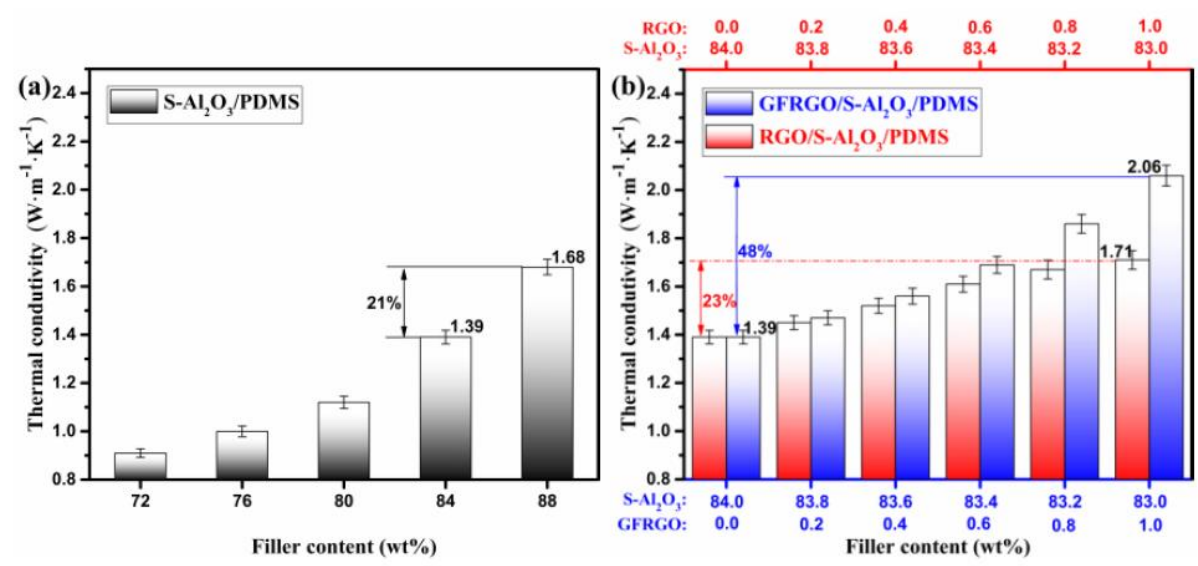

Figure 5. Thermal conductivity of (a) $\mathrm{S}-\mathrm{Al}_{2} \mathrm{O}_{3} / \mathrm{PDMS}$ composites and (b) GFRGO/S- $\mathrm{Al}_{2} \mathrm{O}_{3} / \mathrm{PDMS}$ and $\mathrm{RGO} / \mathrm{S}-\mathrm{Al}_{2} \mathrm{O}_{3} / \mathrm{PDMS}$ composites with different filler contents. 
Table 1. Thermal conductivity enhancement (TCE) in polymer-based $\mathrm{S}-\mathrm{Al}_{2} \mathrm{O}_{3}$ composites.

\begin{tabular}{|c|c|c|c|}
\hline Matrix & Filler & TCE (\%) & References \\
\hline Epoxy & $22.90 \% \mathrm{Ag}$ decorated $\mathrm{S}-\mathrm{Al}_{2} \mathrm{O}_{3}$ hybrid & 6 & [13] \\
\hline Epoxy & $70 \% \mathrm{Ag}$ modified $\mathrm{S}-\mathrm{Al}_{2} \mathrm{O}_{3}$ hybrid & 16 & [39] \\
\hline Natural rubber & 10 vol\% S- $\mathrm{Al}_{2} \mathrm{O}_{3}$-poly(dopamine)-Ag hybrid & 15 & [40] \\
\hline Epoxy & $70 \%$ GO coating S- $\mathrm{Al}_{2} \mathrm{O}_{3}$ hybrid & 58 & [14] \\
\hline Silicone rubber & $89 \% \mathrm{~S}-\mathrm{Al}_{2} \mathrm{O}_{3}+1 \%$ RGO & 47 & [21] \\
\hline Epoxy & $68.63 \% \mathrm{~S}-\mathrm{Al}_{2} \mathrm{O}_{3}+1.37 \% \mathrm{Ag}$ & 43 & [41] \\
\hline Epoxy & $22.5 \% \mathrm{~S}-\mathrm{Al}_{2} \mathrm{O}_{3}+7.5 \% \mathrm{BN}$ & 45 & [42] \\
\hline \multirow[t]{2}{*}{ Epoxy } & $79 \% \mathrm{~S}-\mathrm{Al}_{2} \mathrm{O}_{3}+1 \%$ graphene & 20 & [43] \\
\hline & $45 \% \mathrm{~S}-\mathrm{Al}_{2} \mathrm{O}_{3}+5 \%$ AlN & 17 & \\
\hline \multirow[t]{2}{*}{ Epoxy } & $45 \% \mathrm{~S}-\mathrm{Al}_{2} \mathrm{O}_{3}+5 \%$ AlN/graphene hybrid & 24 & [44] \\
\hline & $45 \% \mathrm{~S}^{-\mathrm{Al}_{2} \mathrm{O}_{3}+5 \% \text { AlN/CNT hybrid }}$ & 20 & \\
\hline \multirow{2}{*}{ PDMS } & $83 \% \mathrm{~S}-\mathrm{Al}_{2} \mathrm{O}_{3}+1 \% \mathrm{RGO}$ & 23 & \\
\hline & $83 \% \mathrm{~S}-\mathrm{Al}_{2} \mathrm{O}_{3}+1 \%$ GFRGO & 48 & This work \\
\hline
\end{tabular}

The thermal resistance of silicone-based $\mathrm{S}-\mathrm{Al}_{2} \mathrm{O}_{3}$ composites is also a crucial thermally conductive property index. Figure $6 \mathrm{a}$, $\mathrm{b}$ depict the thermal resistance of $\mathrm{S}-\mathrm{Al}_{2} \mathrm{O}_{3}, \mathrm{GFRGO} / \mathrm{S}-\mathrm{Al}_{2} \mathrm{O}_{3}$ and $\mathrm{RGO} / \mathrm{S}-\mathrm{Al}_{2} \mathrm{O}_{3}$ filled PDMS composites. The thermal resistance of $\mathrm{S}-\mathrm{Al}_{2} \mathrm{O}_{3} / \mathrm{PDMS}$ composites has been on a continuous decrease, with increasing $\mathrm{S}-\mathrm{Al}_{2} \mathrm{O}_{3}$ loading in Figure $6 \mathrm{a}$. At a filler content of $84 \%$, the thermal resistance of $\mathrm{S}-\mathrm{Al}_{2} \mathrm{O}_{3} / \mathrm{PDMS}$ composites is $0.262{ }^{\circ} \mathrm{C} / \mathrm{W}$. While when $88 \% \mathrm{~S}-\mathrm{Al}_{2} \mathrm{O}_{3}$ is added, it drops to $0.225{ }^{\circ} \mathrm{C} / \mathrm{W}$, only reduced by about $14 \%$, which is accompanied by the decline of constructability and the augment of density. The lower the thermal resistance, the more effective the heat conduction is. The loading of graphene in silicone-based S- $\mathrm{Al}_{2} \mathrm{O}_{3}$ composites is expected to induce a diminution in its thermal resistance. GFRGO/S- $\mathrm{Al}_{2} \mathrm{O}_{3} / \mathrm{PDMS}$ and $\mathrm{RGO} / \mathrm{S}-\mathrm{Al}_{2} \mathrm{O}_{3} / \mathrm{PDMS}$ composites do have the same declining trend in the thermal resistance, with the addition of GFRGO and RGO. Indeed, this highlights the role of graphene having different shapes, which can replace a fraction of $\mathrm{S}-\mathrm{Al}_{2} \mathrm{O}_{3}$ and serve as thermally conductive enhancer. It is illustrated that new and effective heat-conductive paths were established to reduce interfacial thermal resistance between the binary-filler hybrid and PDMS [45]. When the total filler content is fixed at $84 \%$, the thermal resistance of GFRGO/S- $\mathrm{Al}_{2} \mathrm{O}_{3} / \mathrm{PDMS}$ composites with GFRGO of $1 \%$ is presented with lower values, with a reduction of $42 \%$, when compared to that without graphene. Meanwhile, it is observed that GFRGO significantly outperforms that of RGO counterparts, too. The decline of thermal resistance of the GFRGO/S- $\mathrm{Al}_{2} \mathrm{O}_{3} / \mathrm{PDMS}$ composites is greater than that observed for $\mathrm{RGO} / \mathrm{S}-\mathrm{Al}_{2} \mathrm{O}_{3} / \mathrm{PDMS}$ composites in the same content of graphene. The thermal resistance value of the GFRGO/S- $\mathrm{Al}_{2} \mathrm{O}_{3} / \mathrm{PDMS}$ composites declines to a value of $0.152{ }^{\circ} \mathrm{C} / \mathrm{W}$ with GFRGO of $1 \%$, lower than $0.212{ }^{\circ} \mathrm{C} / \mathrm{W}$ of the $\mathrm{RGO} / \mathrm{S}-\mathrm{Al}_{2} \mathrm{O}_{3} / \mathrm{PDMS}$ composites. Compare to flaked RGO, near-spherical GFRGO and spherical S- $\mathrm{Al}_{2} \mathrm{O}_{3}$ can form stronger interface interaction with PDMS and built up more favorable isotropic thermal conductivity pathways [46]. The size of GFRGO is greater than RGO, so has more energetic effects on the $\mathrm{S}-\mathrm{Al}_{2} \mathrm{O}_{3} / \mathrm{PDMS}$ composites [47]. Therefore, regarding thermal resistance, the GFRGO is more suitable for $\mathrm{S}-\mathrm{Al}_{2} \mathrm{O}_{3} / \mathrm{PDMS}$ composites, which benefit from the shape and size of the enhancer, compared with RGO.

An infrared thermal imaging technique is used for investigating the heat diffusivity of silicone-based S- $\mathrm{Al}_{2} \mathrm{O}_{3}$ composites directly. GFRGO/S- $\mathrm{Al}_{2} \mathrm{O}_{3} / \mathrm{PDMS}$ composites with GFRGO of $1 \%$ and $\mathrm{S}-\mathrm{Al}_{2} \mathrm{O}_{3}$ of $83 \%$, RGO/S- $\mathrm{Al}_{2} \mathrm{O}_{3} / \mathrm{PDMS}$ composites with RGO of $1 \%$ and $\mathrm{S}-\mathrm{Al}_{2} \mathrm{O}_{3}$ of $83 \%$, and $\mathrm{S}-\mathrm{Al}_{2} \mathrm{O}_{3} / \mathrm{PDMS}$ composites with $\mathrm{S}-\mathrm{Al}_{2} \mathrm{O}_{3}$ of $84 \%$ were subjected to cycles of heating and cooling. Figure 7 displays their surface temperature variations with time, during a thermography test by an infrared thermal imager. To investigate the heat absorption property, they were put on a heating round-platform $\left(90^{\circ} \mathrm{C}\right)$, heated for $5 \mathrm{~min}$ and the changes in temperature were observed. Detailed temperature distribution images acquired subsequently at various times during the heating process are shown in Figure $7 \mathrm{a}$. Obviously, GFRGO/S- $\mathrm{Al}_{2} \mathrm{O}_{3} / \mathrm{PDMS}$ composites can absorb the quantity of heat most efficiently from the hot-stage with the express and noticeable color 
variance, followed by RGO/S- $\mathrm{Al}_{2} \mathrm{O}_{3} / \mathrm{PDMS}$ and $\mathrm{S}-\mathrm{Al}_{2} \mathrm{O}_{3} / \mathrm{PDMS}$ composites, respectively, indicating that GFRGO/S- $\mathrm{Al}_{2} \mathrm{O}_{3} / \mathrm{PDMS}$ composites exhibit the best thermal response among them. From Figure $7 \mathrm{~b}$, the detailed heating-up behavior of them from the heating curves can be seen. The surface center temperature was chosen as the observation spot. The temperature of GFRGO/S- $\mathrm{Al}_{2} \mathrm{O}_{3} / \mathrm{PDMS}$ composites started to steady at $150 \mathrm{~s}$, about 45 s earlier than the RGO/S- $\mathrm{Al}_{2} \mathrm{O}_{3} / \mathrm{PDMS}$ and $\mathrm{S}-\mathrm{Al}_{2} \mathrm{O}_{3} / \mathrm{PDMS}$ composites. This implies that the temperature of GFRGO/S- $\mathrm{Al}_{2} \mathrm{O}_{3} / \mathrm{PDMS}$ composites rises faster than other specimens. The steady temperature of GFRGO/S- $\mathrm{Al}_{2} \mathrm{O}_{3} / \mathrm{PDMS}, \mathrm{RGO} / \mathrm{S}-\mathrm{Al}_{2} \mathrm{O}_{3} / \mathrm{PDMS}$ and $\mathrm{S}-\mathrm{Al}_{2} \mathrm{O}_{3} / \mathrm{PDMS}$ composites slightly fluctuates at $73.3,70.6$ and $68.2^{\circ} \mathrm{C}$, respectively. All specimens stabilize at an invariable temperature over time, because of their stable state heat conduction [48]. Therefore, we can conclude that the heat absorption property of GFRGO/S- $\mathrm{Al}_{2} \mathrm{O}_{3} / \mathrm{PDMS}$ composites is best in the midst of them. To study their heat dissipation property, the specimens were withdrawn from heat source and placed on the disk to cool down. The quick and obvious color shift of specimens was observed in the cooling course. The colors of GFRGO/S- $\mathrm{Al}_{2} \mathrm{O}_{3} / \mathrm{PDMS}$ composites at the same time were lighter than $\mathrm{RGO} / \mathrm{S}-\mathrm{Al}_{2} \mathrm{O}_{3} / \mathrm{PDMS}$ and $\mathrm{S}-\mathrm{Al}_{2} \mathrm{O}_{3} / \mathrm{PDMS}$ composites, reflecting the improved heat release. Three temperature-cooling time lines of the corresponding specimens are displayed in Figure $7 \mathrm{~b}$. All specimens cooled down at varying heat dissipation speeds and exhibited relatively big decreasing amplitude in the surface temperature in the beginning. After that, they showed a gradual reduction in temperature change. Compared with $\mathrm{RGO} / \mathrm{S}-\mathrm{Al}_{2} \mathrm{O}_{3} / \mathrm{PDMS}$ and $\mathrm{S}-\mathrm{Al}_{2} \mathrm{O}_{3} / \mathrm{PDMS}$ composites, the GFRGO/S- $\mathrm{Al}_{2} \mathrm{O}_{3} / \mathrm{PDMS}$ composites showed much faster reduction with time. The surface temperature of GFRGO/S- $\mathrm{Al}_{2} \mathrm{O}_{3} / \mathrm{PDMS}$ composites is lower than RGO/S- $\mathrm{Al}_{2} \mathrm{O}_{3} / \mathrm{PDMS}$ and $\mathrm{S}-\mathrm{Al}_{2} \mathrm{O}_{3} / \mathrm{PDMS}$ composites after $305 \mathrm{~s}$. The heat dissipation property of GFRGO/S- $\mathrm{Al}_{2} \mathrm{O}_{3} / \mathrm{PDMS}$ composites is best compared with the RGO/S- $\mathrm{Al}_{2} \mathrm{O}_{3} / \mathrm{PDMS}$ and $\mathrm{S}-\mathrm{Al}_{2} \mathrm{O}_{3} / \mathrm{PDMS}$ composites. To sum up, both the heat absorption and dissipation properties of three specimens take a uniform sequence as follows: GFRGO/S- $\mathrm{Al}_{2} \mathrm{O}_{3} / \mathrm{PDMS}>\mathrm{RGO} / \mathrm{S}-\mathrm{Al}_{2} \mathrm{O}_{3} / \mathrm{PDMS}>\mathrm{S}-\mathrm{Al}_{2} \mathrm{O}_{3} / \mathrm{PDMS}$. The two properties demonstrate that the GFRGO/S- $\mathrm{Al}_{2} \mathrm{O}_{3} / \mathrm{PDMS}$ composites show the best thermal management capability, because of their superiority in thermal conductivity and thermal resistance [49-51]. It follows that GFRGO could help in improving the capacity of heat transfer of silicone-based $\mathrm{S}-\mathrm{Al}_{2} \mathrm{O}_{3}$ composites effectively.
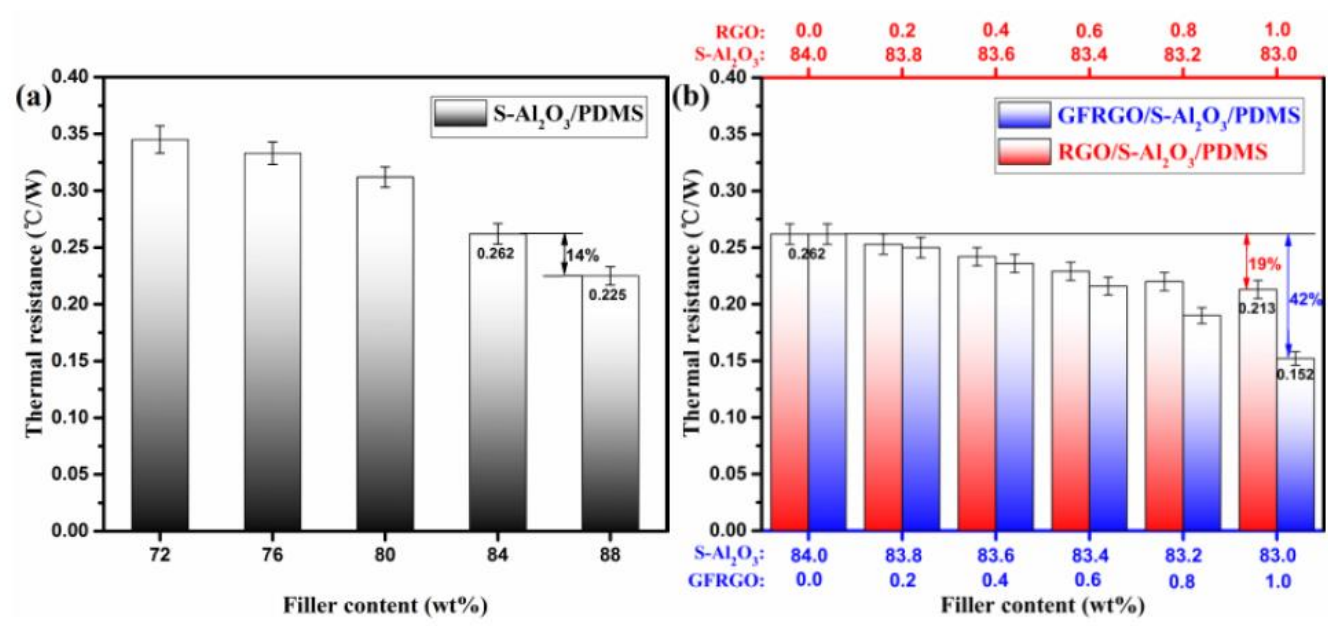

Figure 6. Thermal resistance of (a) $\mathrm{S}-\mathrm{Al}_{2} \mathrm{O}_{3} / \mathrm{PDMS}$ composites and (b) GFRGO/S- $\mathrm{Al}_{2} \mathrm{O}_{3} / \mathrm{PDMS}$ and $\mathrm{RGO} / \mathrm{S}-\mathrm{Al}_{2} \mathrm{O}_{3} / \mathrm{PDMS}$ composites with different filler contents. 

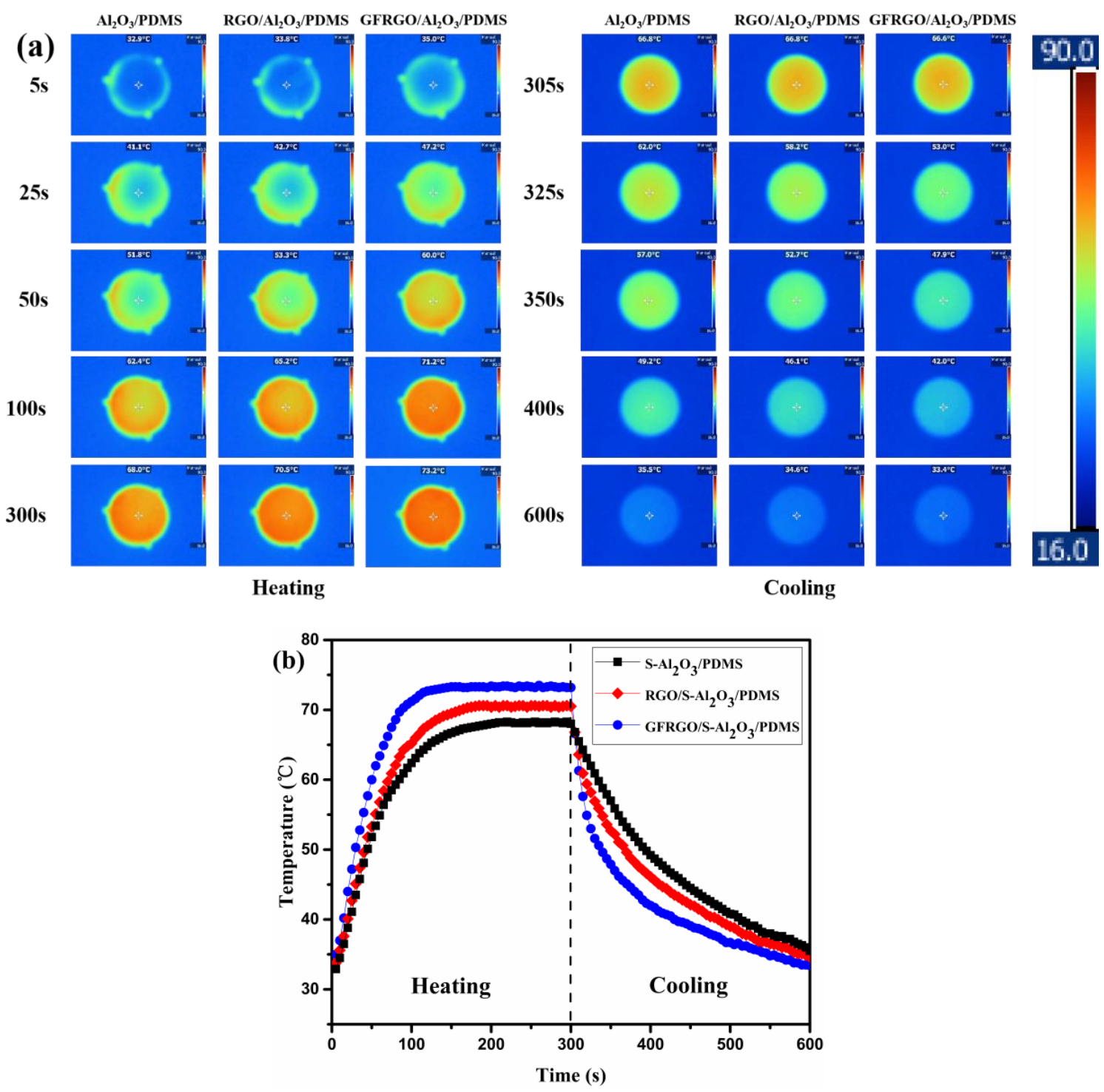

Figure 7. (a) Infrared thermal images and (b) surface center temperature variations of $\mathrm{S}-\mathrm{Al}_{2} \mathrm{O}_{3} / \mathrm{PDMS}$, $\mathrm{RGO} / \mathrm{S}-\mathrm{Al}_{2} \mathrm{O}_{3} / \mathrm{PDMS}$ and GFRGO/S- $\mathrm{Al}_{2} \mathrm{O}_{3} / \mathrm{PDMS}$ composites.

\section{Conclusions}

In this work, GFRGO, with a globular flower-like structure, has been prepared successfully by a spray-assisted self-assembly, investigated as a thermal conductivity enhancer for silicone-based S- $\mathrm{Al}_{2} \mathrm{O}_{3}$ composites. Like RGO, the introduction of GFRGO is conducive to the density of silicone-based $\mathrm{S}-\mathrm{Al}_{2} \mathrm{O}_{3}$ composites. In contrast to RGO, GFRGO, with its superb micro-structure, enhances the thermally conductive properties of silicone-based $\mathrm{S}-\mathrm{Al}_{2} \mathrm{O}_{3}$ composites more effectively, which can be ascribed to the formation of the 3D isotropic thermally conductive network with S- $\mathrm{Al}_{2} \mathrm{O}_{3}$. When the content of S- $\mathrm{Al}_{2} \mathrm{O}_{3}$ and graphene is fixed at $84 \mathrm{wt} \%$, the thermal conductivity enhancement of GFRGO/S- $\mathrm{Al}_{2} \mathrm{O}_{3} / \mathrm{PDMS}$ composites with $1 \mathrm{wt} \%$ of GFRGO reached $48 \%$, about 2.1 times that of $\mathrm{RGO} / \mathrm{S}-\mathrm{Al}_{2} \mathrm{O}_{3} / \mathrm{PDMS}$ composites $(23 \%)$. Meanwhile, the thermal resistance of the GFRGO/S- $\mathrm{Al}_{2} \mathrm{O}_{3} / \mathrm{PDMS}$ composites declined to $0.152{ }^{\circ} \mathrm{C} / \mathrm{W}$ from $0.262{ }^{\circ} \mathrm{C} / \mathrm{W}$ of the S- $\mathrm{Al}_{2} \mathrm{O}_{3} / \mathrm{PDMS}$ composites, lower than the $0.213{ }^{\circ} \mathrm{C} / \mathrm{W}$ of the $\mathrm{RGO} / \mathrm{S}-\mathrm{Al}_{2} \mathrm{O}_{3} / \mathrm{PDMS}$ composites. Importantly, GFRGO/S- $\mathrm{Al}_{2} \mathrm{O}_{3} / \mathrm{PDMS}$ composites display better thermal management capability than the other two composites during the heat transfer process. Thus, GFRGO is a candidate for thermal conductivity enhancing of the light-weight and high-performance thermal interface materials. 
Author Contributions: This study was conducted by W.L., T.L. and J.G. with project support from J.G. W.L., X.Z. and Z.L. prepared the manuscript. All the other authors discussed the results. All authors have read and agree to the published version of the manuscript.

Funding: The Special Funds for Applied Science and Technology Research and Development of Guangdong Province (2015B090925022) and the Guangdong Public Welfare Fund and Ability Construction Project (2016A010103037).

Conflicts of Interest: The authors declare no conflict of interest.

\section{References}

1. Hansson, J.; Nilsson, T.M.J.; Ye, L.; Liu, J. Novel nanostructured thermal interface materials: A review. Int. Mater. Rev. 2018, 63, 22-45. [CrossRef]

2. Leung, S.N. Thermally conductive polymer composites and nanocomposites: Processing-structure-property relationships. Compos. Part B Eng. 2018, 150, 78-92. [CrossRef]

3. Chung, D.D.L. Thermal interface materials. J. Electron. Mater. 2020, 49, 268-270. [CrossRef]

4. Razeeb, K.M.; Dalton, E.; Cross, G.L.W.; Robinson, A.J. Present and future thermal interface materials for electronic devices. Int. Mater. Rev. 2018, 63, 1-21. [CrossRef]

5. Xu, X.; Chen, J.; Zhou, J.; Li, B. Thermal conductivity of polymers and their nanocomposites. Adv. Mater. 2018, 30, 1705544. [CrossRef] [PubMed]

6. Cui, Y.; Li, M.; Hu, Y. Emerging interface materials for electronics thermal management: Experiments, modeling, and new opportunities. J. Mater. Chem. C 2020. [CrossRef]

7. Mai, V.-D.; Lee, D.-I.; Park, J.-H.; Lee, D.-S. Rheological properties and thermal conductivity of epoxy resins filled with a mixture of alumina and boron nitride. Polymers 2019, 11, 597. [CrossRef]

8. Zhang, P.; Ding, X.; Wang, Y.; Shu, M.; Gong, Y.; Zheng, K.; Tian, X.; Zhang, X. Low-melting-point alloy continuous network construction in a polymer matrix for thermal conductivity and electromagnetic shielding enhancement. ACS Appl. Polym. Mater. 2019, 1, 2006-2014. [CrossRef]

9. Zhang, Y.; Heo, Y.J.; Son, Y.R.; In, I.; An, K.H.; Kim, B.J.; Park, S.J. Recent advanced thermal interfacial materials: A review of conducting mechanisms and parameters of carbon materials. Carbon 2019, 142, 445-460. [CrossRef]

10. An, D.; Cheng, S.; Xi, S.; Zhang, Z.; Duan, X.; Ren, Y.; Li, J.; Sun, Z.; Liu, Y.; Wong, C.-P. Flexible thermal interfacial materials with covalent bond connections for improving high thermal conductivity. Chem. Eng. J. 2020, 383, 123151. [CrossRef]

11. Mehra, N.; Mu, L.; Ji, T.; Yang, X.; Kong, J.; Gu, J.; Zhu, J. Thermal transport in polymeric materials and across composite interfaces. Appl. Mater. Today 2018, 12, 92-130. [CrossRef]

12. Wen, Y.; Chen, C.; Feng, Y.; Xue, Z.; Zhou, X.; Xie, X.; Mai, Y.-W. Effects of selective distribution of alumina micro-particles on rheological, mechanical and thermal conductive properties of asphalt/SBS/alumina composites. Compos. Sci. Technol. 2020, 186, 107917. [CrossRef]

13. Wang, Z.; Yang, M.; Cheng, Y.; Liu, J.; Xiao, B.; Chen, S.; Huang, J.; Xie, Q.; Wu, H. Dielectric properties and thermal conductivity of epoxy composites using quantum-sized silver decorated core/shell structured alumina/polydopamine. Compos. Part A Appl. Sci. Manuf. 2019, 118, 302-311. [CrossRef]

14. Feng, Y.Z.; He, C.G.; Wen, Y.F.; Zhou, X.P.; Xie, X.L.; Ye, Y.S.; Mai, Y.W. Multi-functional interface tailoring for enhancing thermal conductivity, flame retardancy and dynamic mechanical property of epoxy/Al2O3 composites. Compos. Sci. Technol. 2018, 160, 42-49. [CrossRef]

15. Ouyang, Y.G.; Hou, G.L.; Bai, L.Y.; Li, B.; Yuan, F. Constructing continuous networks by branched alumina for enhanced thermal conductivity of polymer composites. Compos. Sci. Technol. 2018, 165, 307-313. [CrossRef]

16. Zhang, S.; Ke, Y.; Cao, X.; Ma, Y.; Wang, F. Effect of Al2O3 fibers on the thermal conductivity and mechanical properties of high density polyethylene with the absence and presence of compatibilizer. J. Appl. Polym. Sci. 2012, 124, 4874-4881. [CrossRef]

17. Permal, A.; Devarajan, M.; Hung, H.L.; Zahner, T.; Lacey, D.; Ibrahim, K. Improved thermal and mechanical properties of aluminium oxide filled epoxy composites by reinforcing milled carbon fiber by partial replacement method. J. Mater. Sci. Mater. Electron. 2017, 28, 13487-13495. [CrossRef] 
18. Yeo, H.; Islam, A.M.; You, N.H.; Ahn, S.; Goh, M.; Hahn, J.R.; Jang, S.G. Characteristic correlation between liquid crystalline epoxy and alumina filler on thermal conducting properties. Compos. Sci. Technol. 2017, 141, 99-105. [CrossRef]

19. Chena, C.; Xueb, Y.; Lib, X.; Wenb, Y.; Liub, J.; Xueb, Z.; Shia, D.; Zhoub, X.; Xieb, X.; Maib, Y.-W. High-performance epoxy/binary spherical alumina composite as underfill material for electronic packaging. Compos. Part A Appl. Sci. Manuf. 2019, 118, 67-74. [CrossRef]

20. Liu, Y.; Chen, Z.; Shen, Y.; Zhou, Y.; Wang, D.; Lei, Z.; Feng, W.; Min, Z. Silicone-based alumina composites synthesized through in situ polymerization for high thermal conductivity and thermal stability. Mater. Lett. 2020, 261, 127002. [CrossRef]

21. Zhang, Y.; Yu, W.; Zhang, L.; Yin, J.; Wang, J.; Xie, H. Thermal conductivity and mechanical properties of low-density silicone rubber filled with $\mathrm{Al} 2 \mathrm{O} 3$ and graphene nanoplatelets. J. Therm. Sci. Eng. Appl. 2018, 10, 011014. [CrossRef]

22. Balandin, A.A. Thermal properties of graphene and nanostructured carbon materials. Nat. Mater. 2011, 10, 569-581. [CrossRef] [PubMed]

23. Nika, D.L.; Balandin, A.A. Phonons and thermal transport in graphene and graphene-based materials. Rep. Phys. 2017, 80, 036502. [CrossRef] [PubMed]

24. Tiwari, S.K.; Sahoo, S.; Wang, N.; Huczko, A. Graphene research and their outputs: Status and prospect. J. Sci. Adv. Mater. Devices 2020. [CrossRef]

25. Wu, J.; Feng, S.; Wei, X.; Shen, J.; Lu, W.; Shi, H.; Tao, K.; Lu, S.; Sun, T.; Yu, L.; et al. Facile synthesis of 3D graphene flowers for ultrasensitive and highly reversible gas sensing. Adv. Funct. Mater. 2016, 26, 7462-7469. [CrossRef]

26. Chen, H.; Chen, C.; Liu, Y.; Zhao, X.; Ananth, N.; Zheng, B.; Peng, Li.; Huang, T.; Gao, W.; Gao, C. High-quality graphene microflower design for high-performance Li-S and Al-Ion batteries. Adv. Energy Mater. 2017, 7, 1700051. [CrossRef]

27. Chen, C.; Xi, J.B.; Zhou, E.Z.; Peng, L.; Chen, Z.C.; Gao, C. Porous graphene microflowers for high-performance microwave absorption. Nano Micro Lett. 2018, 10, 26. [CrossRef]

28. Ren, L.; Zeng, X.; Sun, R.; Xu, J.-B.; Wong, C.-P. Spray-assisted assembled spherical boron nitride as fillers for polymers with enhanced thermally conductivity. Chem. Eng. J. 2019, 370, 166-175. [CrossRef]

29. Liang, W.; Ge, X.; Ge, J.; Li, T.; Zhao, T.; Chen, X.; Song, Y.; Cui, Y.; Khan, M.; Ji, J.; et al. Reduced graphene oxide embedded with MQ silicone resin nano-aggregates for silicone rubber composites with enhanced thermal conductivity and mechanical performance. Polymers 2018, 10, 1254. [CrossRef]

30. Macedo, M.I.F.; Bertran, C.A.; Osawa, C.C. Kinetics of the $\gamma \rightarrow \alpha$-alumina phase transformation by quantitative X-ray diffraction. J. Mater. Sci. 2007, 42, 2830-2836. [CrossRef]

31. Mohamed, N.H.; Soliman, F.S.; El Maghraby, H.; Moustfa, Y.M. Thermal conductivity enhancement of treated petroleum waxes, as phase change material, by $\alpha$ nano alumina: Energy storage. Renew. Sustain. Energy Rev. 2017, 70, 1052-1058. [CrossRef]

32. Chen, Y.; Hou, X.; Liao, M.; Dai, W.; Wang, Z.; Yan, C.; Li, He.; Lin, C.-T.; Jiang, N.; Yu, J. Constructing a "pea-pod-like" alumina-graphene binary architecture for enhancing thermal conductivity of epoxy composite. Chem. Eng. J. 2020, 381, 122690. [CrossRef]

33. Idumah, C.I.; Hassan, A. Recently emerging trends in thermal conductivity of polymer nanocomposites. Rev. Chem. Eng. 2016, 32, 413-457. [CrossRef]

34. Liang, W.; Ge, X.; Ge, J.; Li, T.; Zhao, T.; Chen, X.; Zhang, M.; Ji, J.; Pang, X.; Liu, R. Three-dimensional heterostructured reduced graphene oxide-hexagonal boron nitride-stacking material for silicone thermal grease with enhanced thermally conductive properties. Nanomaterials 2019, 9, 938. [CrossRef] [PubMed]

35. Barani, Z.; Mohammadzadeh, A.; Geremew, A.; Huang, C.Y.; Coleman, D.; Mangolini, L.; Kargar, F.; Balandin, A.A. Thermal Properties of the Binary-Filler Hybrid Composites with Graphene and Copper Nanoparticles. Adv. Funct. Mater. 2019, 30, 1904008. [CrossRef]

36. Kargar, F.; Barani, Z.; Balinskiy, M.; Magana, A.S.; Lewis, J.S.; Balandin, A.A. Dual-Functional Graphene Composites for Electromagnetic Shielding and Thermal Management. Adv. Electron. Mater. 2019, 5, 1800558. [CrossRef]

37. Kargar, F.; Barani, Z.; Salgado, R.; Debnath, B.; Lewis, J.S.; Aytan, E.; Lake, R.K.; Balandin, A.A. Thermal percolation threshold and thermal properties of composites with high loading of graphene and boron nitride fillers. ACS Appl. Mater. Interfaces 2018, 10, 37555-37565. [CrossRef] 
38. Lewis, J.S.; Barani, Z.; Magana, A.S.; Kargar, F.; Balandin, A.A. Thermal and Electrical Conductivity Control in Hybrid Composites with Graphene and Boron Nitride Fillers. Mater. Res. Express 2019, 6, 085325. [CrossRef]

39. Ren, L.; Zeng, X.; Zhang, X.; Sun, R.; Tian, X.; Zeng, Y.; Xu, J.-B.; Wong, C.-P. Silver nanoparticle-modified alumina microsphere hybrid composites for enhanced energy density and thermal conductivity. Compos. Part A Appl. Sci. Manuf. 2019, 119, 299-309. [CrossRef]

40. Yang, D.; Ni, Y.; Liang, Y.; Li, B.; Ma, H.; Zhang, L. Improved thermal conductivity and electromechanical properties of natural rubber by constructing Al2O3-PDA-Ag hybrid nanoparticles. Compos. Sci. Technol. 2019, 180, 86-93. [CrossRef]

41. Ren, L.; Li, Q.; Lu, J.; Zeng, X.; Sun, R.; Wu, J.; Xu, J.-B.; Wong, C.-P. Enhanced thermal conductivity for Ag-deposited alumina sphere/epoxy resin composites through manipulating interfacial thermal resistance. Compos. Part A Appl. Sci. Manuf. 2018, 107, 561-569. [CrossRef]

42. Bian, W.; Yao, T.; Chen, M.; Zhang, C.; Shao, T.; Yang, Y. The synergistic effects of the micro-BN and nano-Al2O3 in micro-nano composites on enhancing the thermal conductivity for insulating epoxy resin. Compos. Sci. Technol. 2018, 168, 420-428. [CrossRef]

43. Guan, F.L.; Gui, C.X.; Zhang, H.B.; Jiang, Z.G.; Jiang, Y.; Yu, Z.Z. Enhanced thermal conductivity and satisfactory flame retardancy of epoxy/alumina composites by combination with graphene nanoplatelets and magnesium hydroxide. Compos. Part B Eng. 2016, 98, 134-140. [CrossRef]

44. Gao, Z.; Zhao, L. Effect of nano-fillers on the thermal conductivity of epoxy composites with micro-Al2O3 particles. Mater. Des. 2015, 66, 176-182. [CrossRef]

45. Yu, W.; Xie, H.Q.; Yin, L.Q.; Zhao, J.C.; Xia, L.G.; Chen, L.F. Exceptionally high thermal conductivity of thermal grease: Synergistic effects of graphene and alumina. Int. J. Therm. Sci. 2015, 91, 76-82. [CrossRef]

46. Leung, S.N.; Khan, M.O.; Chan, E.; Naguib, H.; Dawson, F.; Adinkrah, V.; Lakatos-Hayward, L. Analytical modeling and characterization of heat transfer in thermally conductive polymer composites filled with spherical particulates. Compos. Part B Eng. 2013, 45, 43-49. [CrossRef]

47. Wu, H.; Lawrence, T.D. High thermally conductive graphite nanoplatelet/polyetherimide composite by precoating: Effect of percolation and particle size. Polym. Compos. 2013, 34, 2148-2153. [CrossRef]

48. Zhu, Z.; Li, C.; Songfeng, E.; Xie, L.; Geng, R.; Lin, C.-T.; Li, L.; Yao, Y. Enhanced thermal conductivity of polyurethane composites via engineering small/large sizes interconnected boron nitride nanosheets. Compos. Sci. Technol. 2019, 170, 93-100. [CrossRef]

49. Yao, Y.; Sun, J.; Zeng, X.; Sun, R.; Xu, J.B.; Wong, C.P. Construction of 3D skeleton for polymer composites achieving a high thermal conductivity. Small 2018, 14, 1704044. [CrossRef]

50. Ji, C.; Yan, C.; Wang, Y.; Xiong, S.; Zhou, F.; Li, Y.; Sun, R.; Wong, C.-P. Thermal conductivity enhancement of CNT/MoS2/graphene-epoxy nanocomposites based on structural synergistic effects and interpenetrating network. Compos. Part B Eng. 2019, 163, 363-370. [CrossRef]

51. Oh, H.; Kim, J. Fabrication of polymethyl methacrylate composites with silanized boron nitride by in-situ polymerization for high thermal conductivity. Compos. Sci. Technol. 2019, 172, 153-162. [CrossRef]

(C) 2020 by the authors. Licensee MDPI, Basel, Switzerland. This article is an open access article distributed under the terms and conditions of the Creative Commons Attribution (CC BY) license (http://creativecommons.org/licenses/by/4.0/). 